
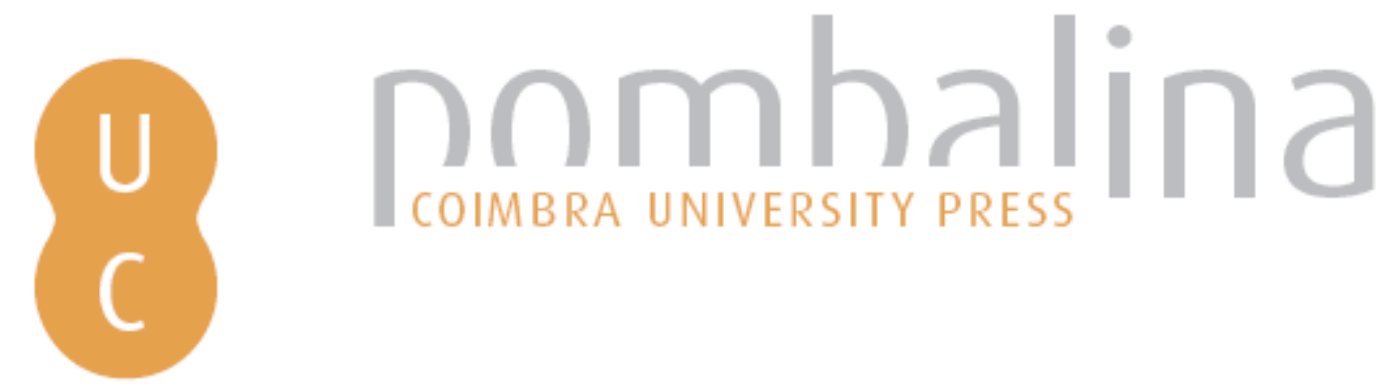

\title{
The evolution of the Wildland Fire Decision Support System (WFDSS): future direction after five years of implementation
}

Autor(es): $\quad$ Noonan-Wright, Erin; Sexton, Tim; Burgard, Mitchell

Publicado por: Imprensa da Universidade de Coimbra

URL

persistente: URI:http://hdl.handle.net/10316.2/34286

DOI: $\quad$ DOI:http://dx.doi.org/10.14195/978-989-26-0884-6_107

Accessed : $\quad$ 26-Apr-2023 12:59:04

A navegação consulta e descarregamento dos títulos inseridos nas Bibliotecas Digitais UC Digitalis, UC Pombalina e UC Impactum, pressupõem a aceitação plena e sem reservas dos Termos e Condições de Uso destas Bibliotecas Digitais, disponíveis em https://digitalis.uc.pt/pt-pt/termos.

Conforme exposto nos referidos Termos e Condições de Uso, o descarregamento de títulos de acesso restrito requer uma licença válida de autorização devendo o utilizador aceder ao(s) documento(s) a partir de um endereço de IP da instituição detentora da supramencionada licença.

Ao utilizador é apenas permitido o descarregamento para uso pessoal, pelo que o emprego do(s) título(s) descarregado(s) para outro fim, designadamente comercial, carece de autorização do respetivo autor ou editor da obra.

Na medida em que todas as obras da UC Digitalis se encontram protegidas pelo Código do Direito de Autor e Direitos Conexos e demais legislação aplicável, toda a cópia, parcial ou total, deste documento, nos casos em que é legalmente admitida, deverá conter ou fazer-se acompanhar por este aviso.

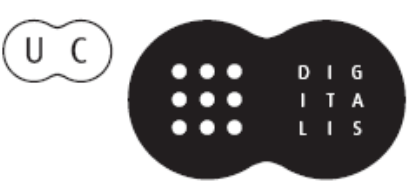




\section{ADVANCES IN}

Forest Fire

\section{RESEARCH}

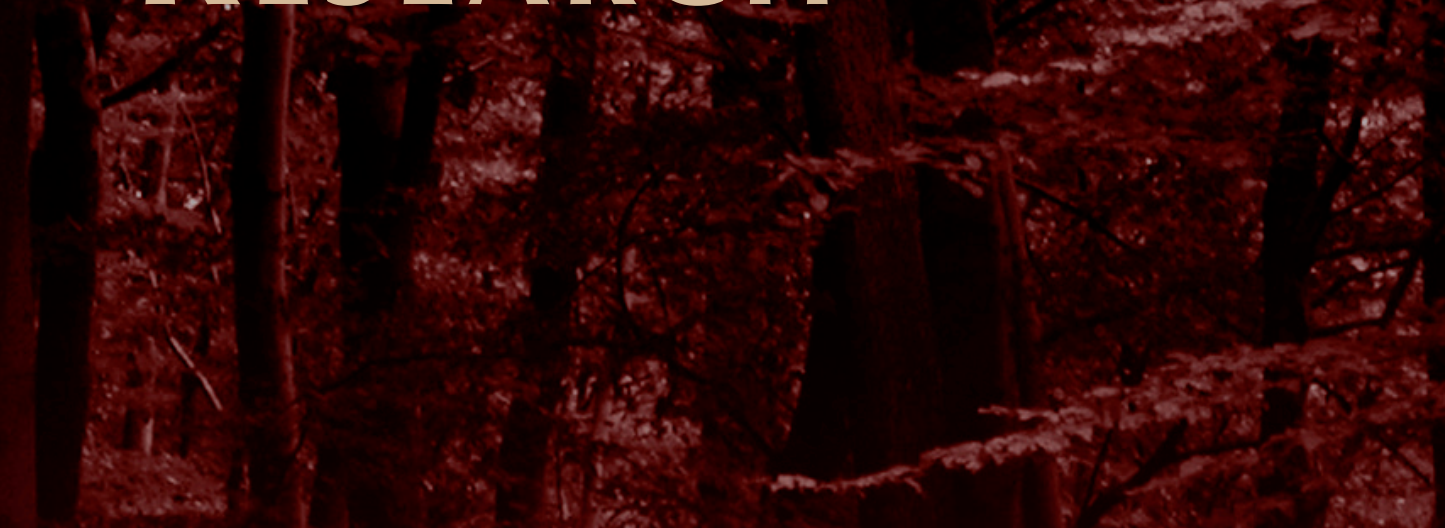

\section{DOMINGOS XAVIER VIEGAS}

\section{EDITOR}




\title{
The evolution of the Wildland Fire Decision Support System (WFDSS): future direction after five years of implementation
}

\author{
Noonan-Wright, Erin ${ }^{\mathrm{a}}$, Sexton, Tim ${ }^{\mathrm{b}}$, Burgard, Mitchell ${ }^{\mathrm{c}}$ \\ ${ }^{a}$ U.S. Forest Service, WFM RDA, 5765 West Broadway St., Missoula, Montana 59808 USA, \\ enoonan02@fs.fed.us \\ ${ }^{b}$ U.S. Forest Service, WFM RDA, 3833 S. Development Ave., Boise, Idaho 83705 USA, \\ timsexton@fs.fed.us \\ ${ }^{c}$ U.S. Forest Service, WFM RDA, $3446^{\text {th }}$ Avenue East, Kalispell, Montana 59901 USA, \\ mburgard@fs.fed.us
}

\begin{abstract}
The Wildland Fire Decision Support System (WFDSS) was unveiled to the United States (U.S.) fire community in 2009 to facilitate a flexible, agile and scalable risk-informed decision-making process on complex wildland fires. Composed of a collection of spatial and non-spatial data, economic, fire behaviour, smoke, and weather tools, the WFDSS was designed to guide a decision-maker through a deliberative and thoughtful decision. After five years of operational use on federal wildland fires, user trends suggest greater involvement with the decisionmaking process and an increase in the number of documented decisions made on wildland fires. Despite these trends, increased wildland fire costs and continued fire-fighter fatalities each year reinforces the need to improve fire management decision-making to achieve better performance. After reviewing the intent, implementation, components and usage statistics of the WFDSS, we discuss the strengths, weaknesses, and further opportunities to support the U.S. fire management community with making risk informed decisions. International audiences who are developing similar wildland fire decision-making systems may find value in evaluating the strengths, opportunities, and lessons learned from a national decision support system like the WFDSS.
\end{abstract}

Keywords: fire management, United States, risk, decision-making, Wildland Fire Management Research Development and Application (WFMRDA)

\section{Introduction}

The Wildland Fire Decision Support System (WFDSS - Noonan-Wright et.al 2011) was officially unveiled to the U.S. fire community in 2009 to facilitate continued implementation of the 1995 U.S. federal fire policy which acknowledged fire as a critical process that will be planned for in land and resource management planning documents (USDI-USDA 2001, 2009). The revised implementation of this policy in 2009 specified "a new wildfire analysis and decision process, the Wildland Fire Decision Support System (WFDSS), to improve decision documentation, risk assessment, decision support, and operational implementation" (NWCG 2009). The integration of the best available science and tools in the WFDSS was intended to increase decision makers' ability to acquire and synthesize information in order to more make timely and applicable risk informed decisions on wildland fires (Zimmerman 2011).

Two decision processes had been in place for federal agency administrators and fire managers to use in making decisions on wildfires. One very simple process, the Wildland Fire Situation Analysis (WFSA) was used for fires necessitating an aggressive suppression response. The WFSA was a PCbased desktop application with decision tree analysis using expert opinions. Another more complicated process, the Wildland Fire Implementation Plan (WFIP) was required for fires that were deemed to be beneficial to natural and cultural resources and might be allowed to achieve land management plan objectives. After several severe wildfire years affecting almost all portions of the United States, federal agency administrators and fire managers from U.S. land management agencies [including the United States Department of Agriculture, National Forest System (USDA FS); the United States Department 
of Interior Bureau of Land Management (USDOI BLM); National Park Service (USDOI - NPS); Bureau of Indian Affairs (USDOI - BIA); and the Fish and Wildlife Service (USDOI - FWS)], agreed that a single process for all wildland fires would be more effective. It was further agreed that the single process would be a deliberative, risk-based process which would provide decision support and also serve as an archive of decisions for organizational learning. Initial research and development of the conceptual design of the WFDSS began in 2005 and was tested during the 2007 and 2008 fire seasons through a new web based fire behaviour model, Fire Spread Probability (FSPro). A decision framework process was quickly added to assist fire and land managers with rapidly evaluating the emerging fire situation and producing a quality strategic decision. The WFDSS was being utilized by all 5 of the largest federal land management agencies in the U.S. by 2010. The primary users of the WFDSS have been Agency Administrators, who have the ultimate responsibility and approval authority for how wildland fire is managed on their home unit. Though the focus of the WFDSS is on strategic decision-making, over time, it has incorporated more tools and data that additionally assist incident command teams and other firefighting resources with gaining situational awareness and developing short-term tactics from the broader strategic direction. Emerging science and technologies are continually integrated, such as the Near-Term and Short-Term fire behaviour models, to further support risk informed decisions that are integral to the WFDSS (Zimmerman 2011).

Despite increased use of a deliberative, risk-based decision process, even the partial costs for suppressing federal fires often exceeds 1 billion dollars a year (Calkin et al. 2005, NIFC 2013). The U.S. Forest Service continues to experience annual wildfire costs of approximately 3 billion dollars a year, when both preparedness and suppression costs are included in the estimate (Lichtenstein, 2014). Costs incurred by other federal, state, and local governments push the total costs of wildland fire in the United States far higher. In addition, there are episodic tragedies of loss of firefighter and civilian lives. Consequently, there is a compelling need to enhance the WFDSS as well as improve user understanding and use of this application.

\section{Risk Assessment Process in the WFDSS}

The WFDSS is a system for wildfire decision support and analysis based on a deliberative decision process (Figure 1). A risk informed decision process in the WFDSS begins with gathering, analysing and synthesizing new and existing information. Land managers are, by definition, geographically oriented decision makers; therefore, much of the WFDSS information is displayed as spatial data over a variety of different map base layers. The location of the fire start, its size, and the responsible agency is populated and available to a decision maker. Maps with reference data layers showing highly valued resources and assets are evaluated with hazard and fire potential to develop a preliminary risk assessment. Management Requirements and Strategic Objectives from land management planning documents are automatically displayed for the fire area. Users develop incident specific requirement and objectives tiered to the Strategic Objectives, informed by the Management Requirements and tailored to the specific spatial and temporal attributes of the fire. A course of action defining operational actions to meet incident specific objectives is drafted, reviewed, and validated. Collectively, the Agency Administrator, local staff and fire specialists develop a decision, which the Agency Administrator has the option of approving or rejecting. If it is approved, the Agency Administrators document the decision with the rationale behind it and provide it to the incident management team that has been assigned to the fire. After approval, a periodic assessment allows a decision maker to revisit their decision and evaluate its relevance to the current fire situation. All parts of a decision require iterative steps to re-evaluate when conditions change and new information is provided. All components of a risk-informed are available in the WFDSS. 
Figure 1. There are seven linear steps to develop and document a wildland fire decision in the WFDSS.

\section{Five Years of Operational Use}

After 5 years of implementation, the need to review how the WFDSS is supporting the field to facilitate and document decisions is necessary. Given the capacity of the WFDSS to store analyses and other components of a risk-informed decision, the ability to query the database has enabled retrospective evaluation of the system, which, in part, is described below.

\subsection{General User Statistics}

User statistics in the WFDSS were summarized to evaluate the over-all use and application of the system. Data were normalized by the total number of federal fires per year and scaled by 1000 in order to compare yearly trends (NWCG 2013).

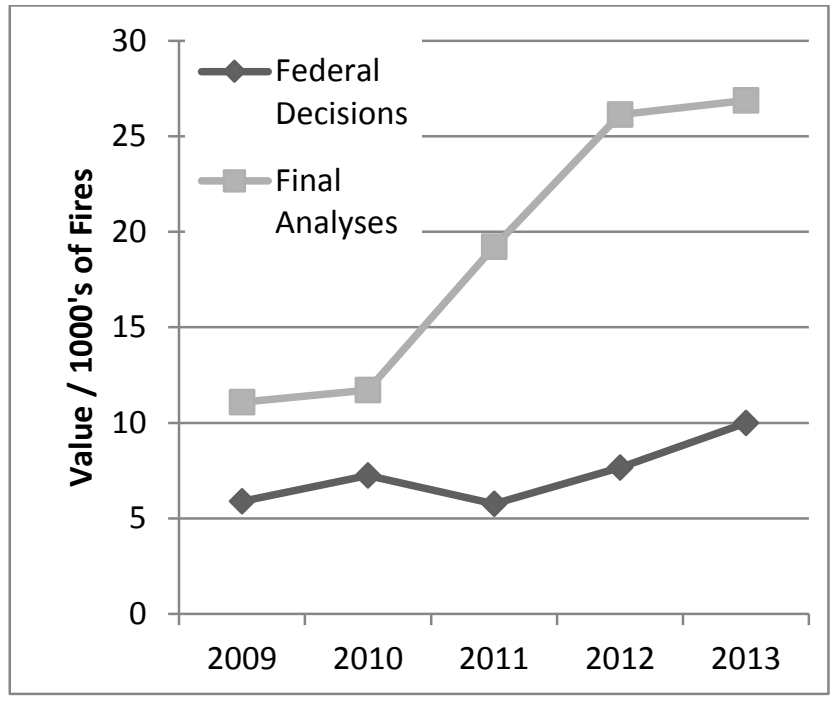

Figure 2. Analyses and Decisions in the WFDSS

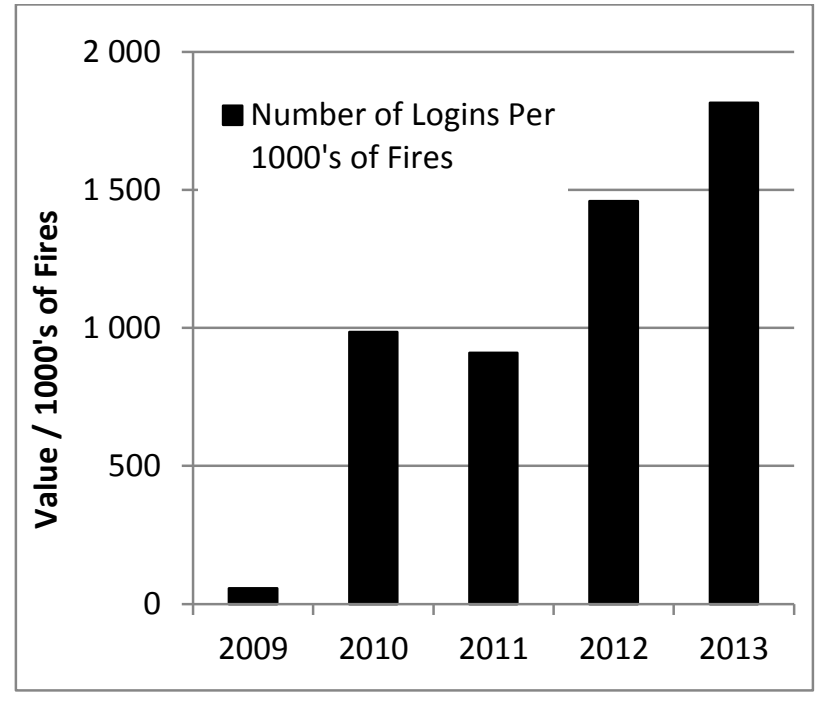

Figure 3. WFDSS Use Since 2009

In Figure 2, it is not surprising that there are more analyses than decisions because multiple analyses would provide part of the information to develop a decision. "Final analyses" are defined as all fire behaviour modelling analyses (Basic, STFB, NTFB, and FSPro) used on wildland fires and formally published in the WFDSS by the fire behaviour specialist. "Federal Decisions" are published documents excluding local, county and state fires that follow a risk assessment process in the WFDSS to document how a wildland fire will be managed. Trends suggest that fire modelling use has been increasing over time with the greatest increase between 2010 and 2012, possibly reflecting the expanded utilization of fire behaviour specialists to support short-term tactics and long-term strategy on wildland fires. There has been a moderate increase in the number of decisions since 2011. The dip in the number of federal decisions in 2011, however, does not correspond with a fewer number of federal fires. In fact, 2011 had more fires than any other year since 2009. Figure 3 shows the number of logins into the WFDSS since 2009 normalized by the total number of federal fires. For example, in 2013, on average, for every thousand federal wildland fires in the U.S. there were 1,800 
logins into the WFDSS (or 1.8 logins per fire), which was a slight increase compared to previous years and suggests greater involvement in the decision support tools in the WFDSS.

\subsection{Fire Behaviour Analysis to Support Decision-making}

Enabling users to gain access to national geo-spatial data layers such as surface and canopy fuels and topography (Rollins 2006) resulted in increased use of fire behaviour modelling systems dependent upon these data sources. The WFDSS contains four primary fire behaviour modelling systems: Basic, Short-term (STFB), Near-term (NTFB) and the Fire Spread Probability (FSPro) Simulator for longer term analyses.

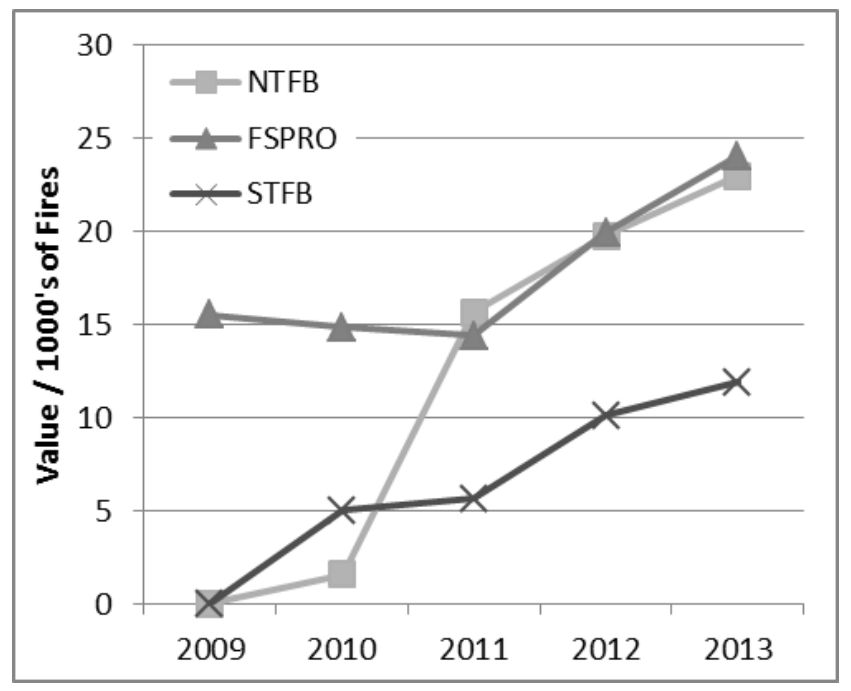

Figure 4. Usage statistics per every thousand federal fires for fire behaviour modeling systems, such as Near-term Fire Behaviour (NTFB), Fire Spread Probability (FSPro) Simulator, and Short-term Fire Behaviour (STFB) in the WFDSS from 2009 to 2013.

The first fire behaviour modelling system in the WFDSS, FSPro, was initially tested in 2007 to support long-term fire behaviour projections. As hardware and software capacity increased, STFB and NTFB modeling systems were added to support short (1-3 days) to mid term (1-7 days) spatial analyses. Usage of FSPro was initially greater than other modeling systems, but an increase in NTFB usage from 2010 to 2011 resulted in almost equal usage to FSPro by 2011. Small fires that were suppressed in the first 24 hours would likely not use fire behaviour modelling systems to gain situational awareness; however, by 2013 for every 1000 fires, there were approximately 11 short-term and over 20 mid to long term fire behaviour analyses simulated for all federal fires. Since 2011, usage for all fire behaviour modelling systems has increased, in addition to the number of federal decisions and logins, suggesting greater usage of the system over time (Figure 4).

\section{Opportunities and Challenges of Risk Informed Decision-making}

\subsection{Social Science and Fire Management}

Developing tools and processes to facilitate smart information sharing, communication, and decisionmaking was an objective of the WFDSS and continues to be a main challenge for wildland fire management (Zimmerman 2011). Identifying and understanding the institutional practices of the people who will use a process or collection of tools is crucial for implementing a decision support process like the WFDSS. Early adopters within the user community were recruited to assist with training others on the WFDSS and this contributed greatly to its acceptance as a process and a useful tool for fire management. Regional leaders, called Geographic Area Editors, were given authority for managing their user community by assigning user roles and access to the WFDSS based on skill level and need. They were relied upon to provide direction and training on how the WFDSS was 
implemented in their region. This collaborative relationship with the user community gave users a sense of ownership and created a feedback loop between them and the developers so that changes and enhancements could be made in a responsive and agile fashion.

The use of the WFDSS to make risk-informed decisions continues to evolve for numerous reasons. The decision makers and their support personnel, including the host unit and incident management team, may vary in their understanding and application of decision science and risk management. This can result in failing to utilize the WFDSS to its full potential by not adequately considering all of the alternatives in developing a course of action or, simply, by using the system to document decisions that were made external to the process

There can be a tendency to reject low probability, large fire growth events when drafting a planning area; a user defined spatial extent that incorporates all of the land the fire may burn during the period that the decision is relevant. Since $2010,16 \%$ of incidents with a decision had two or more planning areas, suggesting that some decision makers draw too small a planning area to manage their fire incident and eventually need to redraw a bigger area as the fire encroaches upon the planning area boundary (Figure 5). When these events occur, decision makers are often forced to rapidly respond to emergency situations and can neglect the careful and deliberative process utilized by the WFDSS. Using a fire behaviour modelling tool such as FSPro could help delineate a planning area that would serve the entire length of the decision. This example illustrates that the process to apply the various tools and information to optimize risk-informed decision-making is still evolving.

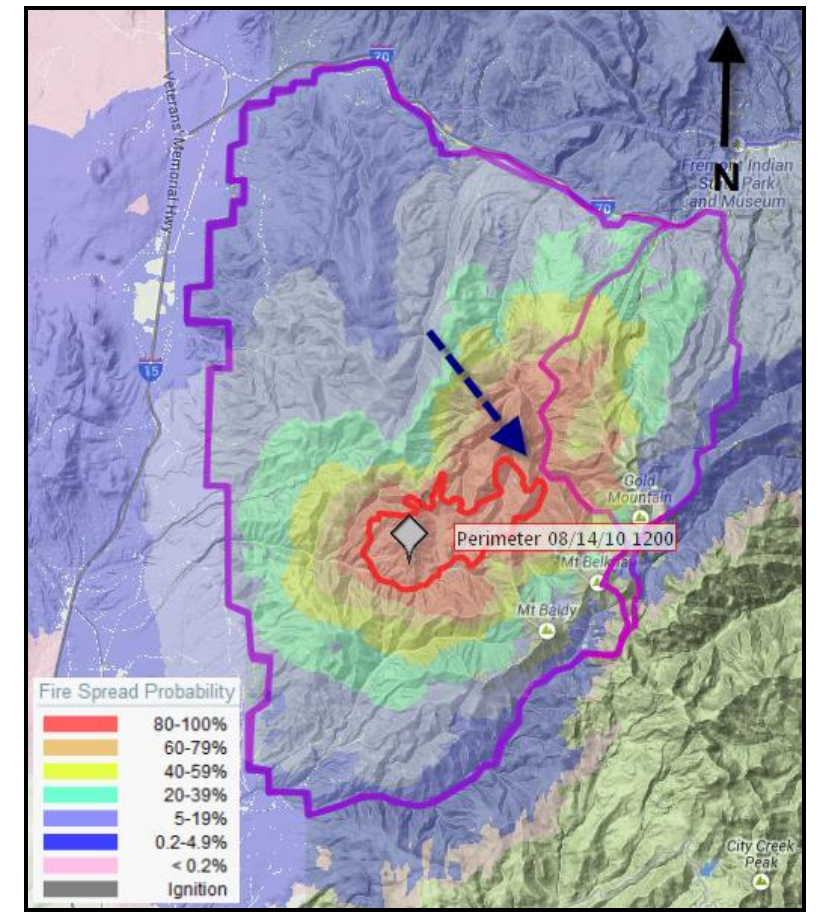

Figure 5. The 8/14 fire perimeter (red line) encroached with 0.2 miles of the first of two planning areas (purple lines) on the east side: the first drawn on 8/14 and the second 8/18 - see black arrow. FSPro is displayed in the background and can be helpful to evaluate fire potential (and the probability) that certain areas will be impacted by the fire over a designated time period, in addition to delineating where the planning area could be located.

\subsection{User-friendly, Best Available Science}

A current effort amongst land management agencies is to take historically text and paper based fire planning documents (referred to as the land and resource management plans and fire management plans) and convert them into digital and spatially explicit formats. As an alternative to providing lengthy text describing where and how a fire will be managed on the landscape, a location can now be 
drawn on a map, and only the pertinent objectives and requirements will be presented for evaluation. Spatial Fire Planning (SFP) is an optional planning process available in the WFDSS that can spatially describe how fire will be managed according to planning documents. The visual depiction of these data allow for greater data control because data managers can upload, manage, and associate spatial polygons, lines or points to represent the planning direction, and make changes as needed throughout the year. The WFDSS initially provided lengthy planning documents in electronic text-based format and made them available to decision makers when they were developing their strategy. While a notable first step, spatial fire planning is the evolution of a process to make information from planning documents more easily consumable during the formulation of wildland fire management strategy and decisions.

Emphasis on pre-fire planning is facilitated by recent advances in quantitative risk assessment (Finney 2005, Calkin et al. 2010, Ager et al. 2011, Scott et al. 2012,) where values on the landscape that are most important are identified and evaluated for their hazard and susceptibility for experiencing harm or benefit from wildland fire. The integration of spatial fire planning and quantitative risk assessment, could result in less exposure to wildland fire fighters, and optimize the strategic wildfire response, i.e. resources are allocated where the probability of containment is highest and values are likely to interact with fire in a negative manner.

\subsection{Information Sharing Via the Risk and Complexity Analysis}

Gathering and communicating timely information on an emerging wildland fire is challenging for an incident commander. The process to determine wildland fire complexity and what level of an incident management organization is needed on a wildland fire was recently merged into one process called a Risk and Complexity Analysis (NWCG 2013). Historically, a separate risk assessment was done by an incident commander (in the field) and a land manager (in the WFDSS). With this change, intelligence gained in the field can be more readily shared with remotely located Agency Administrators who are ultimately responsible for making wildland fire decisions.

The Risk and Complexity Analysis provides users with the ability to make notes and document mitigations for elements identified as moderate or high complexity on wildland fires. Users evaluate components of risk including values (infrastructure, natural and cultural concerns; the proximity and threat of the fire to values; and social and economic concerns), hazard (fuel conditions and fire behaviour) and probability (the likelihood of a long duration event; barriers to fire spread; and the seasonal severity). The Risk and Complexity Analysis is designed to be completed on paper, and the information easily transferred into the WFDSS. Reinforcing a similar risk assessment process across all vested parties is central to the ideology of the WFDSS.

\section{Conclusion}

There are number of decision support systems (DSS) for fire management available internationally (Martell 2011, Mavsar 2013) both for management of fire ignitions and fuels planning. Implemented operationally on a national-scale in 2009, the WFDSS may be considered unique because of its application to a range of different ecosystem types and agencies across the United States. After five years of use, the WFDSS showed a general increase of system application to wildland fires and fire behaviour modelling tools. Challenges remain regarding the optimization of the system to evaluate all facets of ecosystem management, mitigate fire fighter exposure, and utilize fire-fighting resources to manage fire where values are most likely to have a negative impact from wildland fire. As new research methods and products are created, the WFDSS is designed to support and implement new practices to address many of these challenges. Research focused on fire management and decision science (Maguire et al. 2005, Thompson et al. 2013) is especially relevant. Continued investment in technology transfer to the decision makers and support staff is necessary for continued use and elevated application of the WFDSS as wildland fires become larger (Dennison 2014). 


\section{Acknowledgements}

Funding for the WFDSS was provided primarily by the USDA Forest Service Fire and Aviation Management, State and Private Forestry, and the Department of Interior Office of Wildland Fire Coordination. Contributing staff and associated work accomplishments by the Department of Interior Bureau of Indian Affairs, National Park Service, and Office of Wildland Fire Coordination also contributed to the implementation of the WFDSS.

\section{References}

Ager, A.A., Vaillant, N.M., and M.A. Finney. (2011) Integrating Fire Behaviour Models and Geospatial Analysis for Wildland Fire Risk Assessment and Fuel Management Planning. Journal of Combustion. 2011: Article ID 572452: doi: 10.1155/2011/572452 19 p.

Calkin, D. E., Gebert, K. M., Jones, J. G., and Neilson, R. P. (2005) Forest service large fire area burned and suppression expenditure trends, 1970-2002. Journal of Forestry, 103(4), 179-183.

Calkin, David E.; Ager, Alan A.; Gilbertson-Day, Julie, eds. (2010) Wildfire risk and hazard: procedures for the first approximation. Gen. Tech. Rep. RMRS-GTR-235. Fort Collins, CO: U.S. Department of Agriculture, Forest Service, Rocky Mountain Research Station. 62 p.

Dennison, P. E., Brewer, S. C., Arnold, J. D., and M. A. Moritz (2014) Large wildfire trends in the western United States, 1984-2011, Geophys. Res. Lett.(41): 2928-2933, doi:10.1002/2014GL059576.

Finney, M. A. (2005) The challenge of quantitative risk analysis for wildland fire. Forest Ecology and Management. 211(1): 97-108.

Lichtenstein, Mark (2014) Personal communication. US Forest Service, National Headquarters, Fire Budget Branch Chief.

Martell, D. (2011) The Development and Implementation of Forest Fire Management Decision Support Systems in Ontario, Canada: Personal Reflections of Past Practices and Emerging Challenges. Mathematical and Computational Forestry and Natural Resource Sciences. 3 (1): 1826.

Mavsar, R., Gonzalez Caban, A., and E. Varela (2013) The state of development of fire management decision support systems in America and Europe. Forest Policy and Economics (29): 45-55.

Maguire, L.A. and E. A. Albright (2005) Can behavioural decision theory explain risk-averse fire management decisions? Forest Ecology and Management (211): 47-58.

National Interagency Fire Center (2013) Federal Firefighting Costs (Suppression Only). Available online: http://www.nifc.gov/fireInfo/fireInfo_documents/SuppCosts.pdf [Verified 14 July 2014].

National Interagency Fire Center [NIFC] (2013) Total Wildland Fires and Acres (1960-2013). Available online at https://www.nifc.gov/fireInfo/fireInfo_stats_totalFires.html [Verified 09 July 2014].

National Wildfire Coordinating Group [NWCG] (2009) Update on the modifications to the interagency strategy for the implementation of Federal Wildland Fire Management Policy (NWCG \#001-2009). Boise: Idaho. Print.

National Wildfire Coordinating Group [NWCG] (2013) Adoption and Release of the Risk and Complexity Assessment (NWCG \#015-2013). Memorandum and Attachement. Boise: Idaho, 2013. Print.

Noonan-Wright, E.; Opperman, T. S.; Finney, M. A.; Zimmerman, T. G.; Seli, R. C.; Elenz, L. M; Calkin, D. E.; and J. R. Fiedler (2011) Developing the U.S. Wildland Fire Decision Support System (WFDSS). Journal of Combustion. 2011: Article ID 168473: doi: 10.1155/2011/168473. 14 p.

Rollins, M. G. and C. K. Frame, tech. eds. (2006) The LANDFIRE Prototype Project: nationally consistent and locally relevant geospatial data for wildland fire management. Gen. Tech. Rep. 
RMRS-GTR-175. Fort Collins: U.S. Department of Agriculture, Forest Service, Rocky Mountain Research Station. 416 p.

Scott, J. H.; M.P. Thompson, and D.E. Calkin (2013) A wildfire risk assessment framework for land and resource management. Gen. Tech. Rep. RMRS-GTR-315. U.S.Department of Agriculture, Forest Service, Rocky Mountain Research Station. 83 p.

Thompson, M.P., Marcot, B.G., Thompson III, F.R., McNulty,S., Fisher, L.A., Runge, M.C., Cleaves, D. and M. Tomosy (2013) The Science of Decisionmaking: Applications for Sustainable Forest and Grassland Management in the National Forest System. General Technical Report WO-88. 54p.

U.S. Department of the Interior, U.S. Department of Agriculture, U.S. Department of Energy (and others) [USDI - USDA] (2001) Review and update of the 1995 Federal Wildland Fire Management Policy. January 2001. Available at: https://www.nifc.gov/PIO_bb/Policy/FederalWildlandFireManagementPolicy_2001.pdf Verified [14 July 2014].

U.S. Department of the Interior, U.S. Department of Agriculture [USDI-USDA] (2009) Guidance for Implementation of Federal Wildland Fire Management Policy. February 2009. Boise, Idaho, USA, Available at: http://www.nifc.gov/policies/policies_documents/GIFWFMP.pdf [Verified 14 July 2014].

Zimmerman, T. (2011) Fire science application and integration in support of decision-making. Wildfire 2001: 5th International Wildland Fire Conference, South Africa. Available online at: http://www.wildfire2011.org/material/papers/Tom_Zimmerman.pdf Verified [14 July 2014]. 